\title{
Clavien-Dindo Grade IV
}

National Cancer Institute

\section{Source}

National Cancer Institute. Clavien-Dindo Grade IV. NCI Thesaurus. Code C121452.

A life-threatening complication. 